\title{
PENERAPAN MODEL PEMBELAJARAN BERBASIS MASALAH (PROBLEM BASED LEARNING) DALAM MENINGKATKAN HASIL BELAJAR SOSIOLOGI PADA SISWA KELAS XI IPS MA ANNUR AZZUBAIDI KONAWE ${ }^{1}$
}

\section{MPLEMENTATION OF PROBLEM BASED LEARNING MODEL IN IMPROVING THE RESULTS OF SOCIOLOGY LEARNING IN CLASS XI IPS STUDENTS MA ANNUR AZZUBAIDI KONAWE}

\author{
Kiki Zaskia ${ }^{2}$ \\ e-mail: kikizaskia@gmail.com \\ Mursidin T. ${ }^{3}$ \\ e-mail: mursidint@uho.ac.id \\ Hayari $^{3}$ \\ e-mail: hayari@uho.ac.id
}

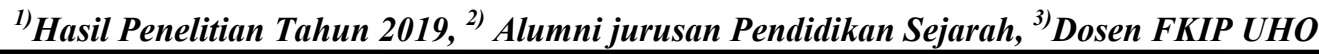

\begin{abstract}
ABSTRAK: Permasalahan dalam penelitian ini adalah 1) Apakah penerapan model pembelajaran berbasis masalah (problem based learning) dapat meningkatkan efektivitas mengajar pada guru sosiologi kelas XI IPS MA Annur Azzubaidi? 2) Apakah penerapan model pembelajaran berbasis masalah (problem based learning) dapat meningkatkan aktivitas belajar sosiologi pada siswa kelas XI IPS MA Annur Azzubaidi? 3) Apakah penerapan model pembelajaran berbasis masalah (problem based learning) dapat meningkatkan hasil belajar sosiologi pada siswa kelas XI IPS MA Annur Azzubaidi?. Penelitian ini adalah Penelitian Tindakan Kelas (PTK) dengan menerapkan model pembelajaran berbasis masalah (problem based learning). Subyek penelitian ini adalah siswa kelas XI IPS MA Annur Azzubaidi Kecamatan Meluhu, Kabupaten Konawe yang berjumlah 26 orang siswa putri. Aspek yang diteliti adalah guru, siswa dan hasil belajar. Prosedur penelitian tindakan kelas terdiri dari 2 siklus pelaksanaan penelitian tindakan tiap siklus dilakukan melalui empat tahap yaitu : 1) Perencanaan, 2) Pelaksanaan Tindakan, 3) Observasi dan Evaluasi serta 4) Refleksi. Indikator keberhasilan proses tindakan yaitu : 1) Indikator efektivitas mengajar guru dikatakan tuntas apabila 90\% telah melaksanakan model pembelajaran berbasis masalah (problem based learning) 2) Indikator aktivitas siswa dikatakan tuntas apabila 90\% telah melaksanakan model pembelajaran berbasis masalah (problem based learning) 3) Indikator hasil belajar sosiologi dikatakan tuntas apabila 80\% siswa telah tuntas dengan perolehan nilai 72 atau lebih, sesuai dengan KKM yang ditetapkan sekolah sebesar 72. Penelitian menunjukkan bahwa 1) Efektivitas mengajar guru dalam melaksanakan model pembelajaran berbasis masalah (problem based learning) yaitu pada siklus I sebesar $84,61 \%$ siklus II sebesar $100 \%$, 2) Aktivitas belajar siswa juga meningkat dengan skor perolehan siklus I sebesar 83,33\% siklus II sebesar 100\% 3) Hasil belajar sosiologi siswa kelas XI IPS MA Annur Azzubaidi Kecamatan Meluhu Kabupaten Konawe dapat ditingkatkan melalui penerapan model pembelajaran berbasis masalah (problem based learning), hal ini terlihat pada siklus I nilai rata-rata siswa 79,56 dengan persentase ketuntasan $61,53 \%$ adapun pada siklus II nilai rata-rata siswa 88,12 dengan persentase ketuntasan $82,60 \%$ sehingga ketuntasan belajar siswa tercapai.
\end{abstract}

Kata Kunci: Efektivitas, Aktivitas, Hasil Belajar

ABSTRACT: The problems in this study are 1) Does the application of the problem based learning model can improve the effectiveness of teaching in class XI IPS MA Annur Azzubaidi sociology teachers? 2) Can the application of the problem based learning model improve sociology learning activities for students of class XI IPS MA Annur Azzubaidi? 3) Does the application of the problem based learning model can improve sociology learning outcomes in class XI IPS MA Annur Azzubaidi ?. This research is a Classroom Action Research (CAR) by applying a problem based 
learning model. The subjects of this study were students of class XI IPS MA Annur Azzubaidi, Meluhu District, Konawe District, totaling 26 female students. The aspects studied were teacher, student and learning outcomes. Classroom action research procedure consists of 2 cycles of action research implementation each cycle carried out through four stages, namely: 1) Planning, 2) Implementation of Actions, 3) Observation and Evaluation and 4) Reflection. Indicators of the success of the action process are: 1) Indicators of teaching effectiveness of teachers are said to be complete if $90 \%$ have implemented problem based learning models 2) Indicators of student activities are said to be complete if $90 \%$ have implemented problem based learning models (problem based learning) 3 ) Indicators of sociology learning outcomes are said to be complete if $80 \%$ of students have completed with 72 or more, in accordance with the KKM set by schools by 72. Research shows that 1) The effectiveness of teaching teachers in implementing problem-based learning models, namely on cycle I amounted to $84.61 \%$ cycle II amounted to $100 \%$, 2) Student learning activities also increased with the acquisition score of cycle I amounted to $83.33 \%$ cycle II amounted to $100 \%$ 3) Sociology learning outcomes of students of class XI IPS MA Annur Azzubaidi District Meluhu District Konawe can be improved through the application of problem based learning models (problems based learning), this can be seen in the first cycle the average value of students 79.56 with a percentage of completeness $61.53 \%$ as for the second cycle the average value of students 88.12 with a percentage of completeness $82.60 \%$ so that students' mastery learning is achieved.

\section{Keywords: Effectiveness, Activities, Learning Outcomes}

\section{PENDAHULUAN}

Tujuan pendidikan nasional di negara Indonesia adalah untuk meningkatkan kualitas manusia Indonesia yaitu manusia yang beriman dan bertakwa terhadap Tuhan Yang Maha Esa, berbudi pekerti luhur, berkepribadian, mandiri, tangguh, cerdas, kreatif, terampil, disiplin, beretos kerja, profesional, bertanggung jawab, dan produktif serta sehat jasmani dan rohani. Pendidikan nasional juga harus menumbuhkan jiwa patriotik dan mempertebal rasa cinta tanah air, meningkatkan semangat kebangsaan dan kesetiakawanan sosial serta kesadaran pada sejarah bangsa dan sikap menghargai jasa para pahlawan serta berorientasi masa depan. Iklim belajar dan mengajar yang dapat menumbuhkan rasa percaya diri dan budaya belajar di kalangan masyarakat terus dikembangkan agar tumbuh sikap dan perilaku kreatif, inovatif, dan keinginan untuk maju (Ahmadi, 2016:48).

Fungsi dan tujuan pendidikan nasional dalam UU RI Nomor 20 Tahun 2003, Bab II Pasal 3 disebutkan sebagai berikut "Pendidikan nasional berfungsi mengembangkan kemampuan dan membentuk watak serta peradaban bangsa yang bermartabat dalam rangka mencerdaskan kehidupan bangsa, bertujuan untuk mengembangkan potensi peserta didik agar menjadi manusia yang beriman dan bertakwa kepada Tuhan Yang Maha Esa, berakhlak mulia, sehat, berilmu, cakap, kreatif, mandiri, dan menjadi warga negara yang demokratis serta bertanggung jawab" (Ahmadi, 2016:49). Dari sudut pandang sosiologi, pendidikan selain berperan menyiapkan manusia untuk memasuki masa depan juga memiliki hubungan dengan transformasi sosial, begitu juga sebaliknya. Berbagai pola sistem pendidikan menggambarkan corak, tradisi, budaya, sosial masyarakat yang ada. Maka yang penting diperhatikan adalah bahwa suatu sistem pendidikan dibangun guna menyiapkan peserta didik sebagai pribadi yang siap pakai pada posisi tertentu (Suwardana, 2017 : 106)

Menyadari siswa yang dihadapi ialah termasuk dalam generasi millenial. Bagi generasi millenial informasi dan teknologi adalah hal yang sudah menjadi bagian hidup mereka, karena mereka lahir dimana akses terhadap informasi, khususnya internet sudah menjadi budaya global, sehingga hal tersebut berpengaruh terhadap nilai-nilai, pandangan dan tujuan hidup mereka. Generasi millenial juga akan menimbulkan tantangan baru bagi praktek manajemen sumber daya manusia (Putra, 2016 : 132). Perkembangan generasi dalam hal ini generasi millenial memberikan peluang dan tantangan tersendiri didunia pendidikan. Korelasi perkembangan teknologi yang 
semakin mutakhir memberikan perspektif dan praktik yang berbeda pada generasi millenial terhadap cara memperoleh informasi diluar dari apa yang mereka dapatkan disekolah.

Keberhasilan pendidikan dipengaruhi oleh perubahan dan pembaharuan dalam segala komponen pendidikan. Adapun komponen yang mempengaruhi pelaksanaan pendidikan meliputi kurikulum, sarana prasarana, guru, siswa, dan model pengajaran yang tepat. Semua komponen tersebut saling terkait dalam mendukung tercapainya tujuan pendidikan yang diinginkan (Djamarah , 2002:123). Penerapan model pembelajaran konvensional (ceramah) yang sering digunakan seringkali menyebabkan siswa cenderung kurang aktif dan hanya berpusat pada guru karena segala informasi terpusat pada guru semata atau hanya bersifat satu arah hasilnya siswa menjadi objek pembelajaran yang seharusnya menjadi subyek pembelajaran. Salah satu paradigma pembelajaran yaitu paradigma konstruktivisme yang dapat mengeksplorasi kemampuan siswa saat ini yang tergolong generasi millenial. Olehnya itu guru perlu untuk melakukan inovasi dalam pembelajaran salah satunya yaitu dengan menerapkan model pembelajaran yang tepat, efektif dan mampu meningkatkan aktivitas belajar siswa. Model pembelajaran adalah kerangka konseptual yang melukiskan prosedur yang sistematik dalam mengorganisasikan pengalaman belajar untuk mencapai tujuan belajar tertentu dan berfungsi sebagai pedoman para perancang pembelajaran dan para pengajar dalam merencanakan dan melakukan aktivitas pembelajaran (Udin, 1994:34).

Salah satu model pembelajaran yang berorientasi konstruktivisme yaitu model pembelajaran berbasis masalah (problem based learning). Arends dalam Abbas (2000:11) mengemukakan pembelajaran berbasis masalah adalah pendekatan pembelajaran siswa pada masalah autentik sehingga siswa dapat menyusun pengetahuan sendiri, menumbuhkan keterampilan yang lebih tinggi dan inquiri, memandirikan siswa, dan dapat meningkatkan kepercayaan diri sendiri. Pitirim Sorokin dalam Soekanto dan Sulistyowati (2014:17) mengatakan bahwa sosiologi adalah suatu ilmu yang mempelajari: (1) Hubungan dan pengaruh timbal balik antara aneka macam gejalagejala sosial misalnya antara gejala ekonomi dengan agama; keluarga dengan moral, hukum dengan ekonomi, gerak masyarakat dengan politik dan sebagainya, (2) Hubungan dan pengaruh timbal balik antara gejala sosial dengan gejala-gejala non-sosial misalnya gejala geografis, biologis, dan sebagainya, (3) Ciri-ciri umum semua jenis gejala-gejala sosial.

Dengan PBL memberikan kesempatan pada siswa dalam mata pelajaran sosiologi tidak hanya sekedar teori belaka yang dipelajari namun mengajak siswa untuk melihat realitas yang ada dilingkungan sekitarnya melalui penyelidikan dalam model pembelajaran berbasis masalah (problem based learning). Berdasarkan hasil observasi awal diketahui bahwa saat pembelajaran sosiologi kelas XI IPS MA Annur Azzubaidi, siswa kurang aktif dan berpartisipasi dalam proses pembelajaran, bahkan sebagian besar siswa memperoleh nilai dibawah 72 sesuai dengan Kriteria Ketuntasan Minimal (KKM) yang telah ditetapkan oleh sekolah, rata-rata nilai perolehan 50,30 dengan persentase ketuntasan 39,13\%. Maka dari itu diharapkan ada pembelajaran yang mampu melibatkan siswa secara langsung untuk selalu aktif dalam kegiatan proses pembelajaran, yang kemudian dapat meningkatkan hasil belajar siswa dengan menerapkan model pembelajaran berbasis masalah (problem based learning) tentunya dengan pertimbangan sarana dan prasarana yang memadai serta kesesuaian materi pokok yang akan dipelajari.

\section{METODE PENELITIAN}

Penelitian ini dilaksanakan pada semester genap tahun pelajaran 2018/2019 yang dilaksanakan dikelas XI IPS MA Annur Azzubaidi Kecamatan Meluhu Kabupaten Konawe. Jenis penelitian merupakan jenis Penelitian Tindakan Kelas (Classroom Action Research) dimana didalam satu siklus terdapat perencanaan (planning), tindakan (acting), pengamatan (observing), penilaian (evaluating) dan refleksi (reflecting). Subjek penelitian ini adalah siswa kelas XI IPS MA Annur Azzubaidi tahun pelajaran 2018/2019, yang berjumlah 26 orang siswa putri. Sedangkan aspek yang diteliti dalam penelitian ini, yaitu :

1. Guru, yaitu mengamati efektivitas mengajar guru dalam menyajikan materi pelajaran sosiologi sesuai dengan model pembelajaran berbasis masalah (problem based learning). 
2. Siswa, yaitu mengamati aktivitas belajar siswa selama mengikuti proses pembelajaran sosiologi dengan menerapkan model pembelajaran berbasis masalah (problem based learnimg).

3. Hasil belajar, yaitu untuk mengetahui peningkatan hasil belajar siswa setelah mengikuti pembelajaran sosiologi melalui penerapan model pembelajaran berbasis masalah (problem based learning).

Prosedur atau langkah-langkah yang digunakan dalam penelitian tindakan kelas ini mengikuti prinsip dasar penelitian tindakan kelas yang berbentuk siklus dengan menggunakan alur seperti gambar 2 berikut ini.

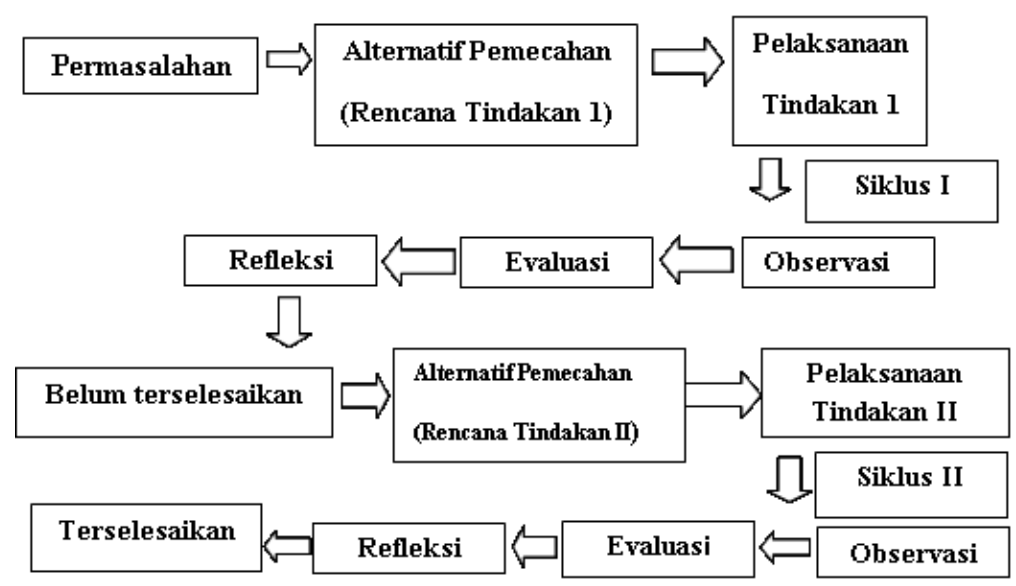

(Sumber: Syukri, 2011:3-7)

Gambar 2.Alur Penelitian Tindakan Kelas

Aqib (2007:30) mengemukakan bahwa prosedur pelaksanaan penelitian tindakan kelas sebagai berikut: (1) Perencanaan, (2) Pelaksanaan Tindakan, (3) Observasi dan Evaluasi serta (4) Refleksi. Secara rinci prosedur penelitian tindakan kelas ini dijabarkan sebagai berikut:

1. Perencanaan, kegiatan yang dilakukan dalam tahap ini yaitu :

a. Membuat perangkat pembelajaran (RPP dan LKS).

b. Membuat lembar observasi untuk guru maupun untuk siswa dalam melihat proses pembelajaran sosiologi di kelas ketika model pembelajaran berbasis masalah diterapkan.

c. Menyiapkan materi pembelajaran dalam rangka membantu siswa memahami konsepkonsep sosiologi dengan baik.

d. Mendesain alat evaluasi untuk melihat sejauh mana sosiologi telah dikuasai siswa.

2. Pelaksanaan tindakan, melaksanakan proses pembelajaran sesuai dengan rencana pelaksanaan pembelajaran yang telah dibuat sesuai dengan model pembelajaran yang digunakan yaitu model pembelajaran berbasis masalah (problem based learning).

3. Observasi dan evaluasi, dilaksanakan observasi terhadap pelaksanaan tindakan dengan menggunakan lembar observasi. Guru sebagai observer mengamati seluruh aktivitas peneliti dan siswa selama mengikuti proses pembelajaran dan melakukan evaluasi untuk mengetahui kemampuan siswa setelah diajar dengan menerapkan model pembelajaran berbasis masalah (problem based learning).

4. Refleksi, hasil yang diperoleh pada tahap observasi/evaluasi dikumpulkan dan dianalisis. Dari hasil tersebut akan dilihat apakah telah memenuhi target yang telah dtetapkan pada indikator kinerja. Jika belum memenuhi target, maka penelitian dilanjutkan ke siklus berikutnya. Kelemahan atau kekurangan yang telah terjadi pada siklus sebelumnya akan diperbaiki pada siklus berikutnya. 
Jenis data dalam penelitian ini adalah data kuantitatif berupa tes hasil belajar, dan data kualitatif berupa pelaksanaan pembelajaran yang diambil melalui lembar observasi. Sumber Data dalam penelitian ini adalah siswa kelas XI IPS MA Annur Azzubaidi dan guru sosiologi kelas XI IPS MA Annur Azzubaidi. Teknik pengumpulan data yang digunakan dalam penelitian tindakan kelas ini adalah: Observasi, dan Tes Hasil Belajar

Teknik analisis data dalam penelitian ini menggunakan teknik analisis kuantitatif dengan teknik analisis deskriptif yaitu menentukan persentase peningkatan efektivitas mengajar guru, peningkatan persentase aktivitas belajar siswa dan menentukan nilai rata-rata siswa serta menggunakan persentase hasil belajar siswa.

Adapun rumus statistik analisis kuantitatif adalah sebagai berikut :

1. Rumus Persentase Efektivitas Mengajar Guru

$$
\% \mathrm{EMG}=\frac{\text { skor perolehan efektifitas mengajar guru }}{\text { skor maksimum }} \times 100 \% \text { (Memes, 2001:34) }
$$

2. Rumus Persentase Aktivitas Belajar Siswa

$\% \mathrm{ABS}=\frac{\text { skor perolehan aktivitas belajar siswa }}{\text { skor maksimum }} \times 100 \%$ (Memes, 2001:36)

3. Menentukan Nilai Rata-Rata

$\bar{X}=\frac{\sum X i}{\text { 国 }}$

Keterangan:

$\bar{X} \quad=$ Nilai Rata-Rata Siswa

$\sum \mathrm{Xi}=$ Jumlah Nilai Siswa

$\mathrm{n} \quad=$ Jumlah Sampel (Sugiyono, 2006:41)

4. Menentukan Persentase Ketuntasan Hasil Belajar Siswa

Keterangan:

Presentase Ketuntasan $=\frac{\sum X}{n} \times 100 \%$

$\sum \mathrm{X} \quad=$ Banyaknya Siswa Yang Tuntas

$\mathrm{n} \quad \quad=$ Jumlah Sampel (Sugiyono, 2006:43)

\section{Indikator Kerja}

Indikator keberhasilan dalam penelitian ini adalah:

1. Efektivitas mengajar guru dikatakan tuntas apabila $90 \%$ telah melaksanakan model pembelajaran berbasis masalah (problem based learning) sesuai dengan skenario pembelajaran.

2. Aktivitas belajar siswa dikatakan tuntas apabila $90 \%$ telah mengikuti model pembelajaran berbasis masalah (problem based learning).

3. Hasil belajar dikatakan tuntas apabila $80 \%$ siswa telah mencapai nilai 72 atau lebih, sesuai Kriteria Ketuntasan Minimal (KKM) yang ditetapkan sekolah sebesar 72.

\section{HASIL PENELITIAN DAN PEMBAHASAN \\ Hasil Penelitian}

Setiap satu siklus dilakukan satu kali pertemuan, tahapan setiap siklus terdiri dari : (a) Perencanaan, (b) Pelaksanaan, (c) Observasi dan Evaluasi, serta (d) Refleksi. Penelitian ini akan dilaksanakan secara berkala sampai mencapai indikator kinerja, batas maksimal pelaksanaan tindakan sampai dua siklus. Sebelum melakukan tindakan dalam penelitian, peneliti terlebih dahulu melakukan observasi awal. Hasil observasi awal menunjukkan pembelajaran sosiologi di kelas XI IPS MA Annur Azzubaidi, bahwa siswa kurang aktif dan berpartisipasi dalam proses pembelajaran, sebagian besar siswa memperoleh nilai dibawah 72 sesuai KKM yang telah ditetapkan oleh sekolah, rata-rata nilai perolehan 50,30 dengan persentase ketuntasan 39,13\%. 
Sebelum melaksanakan penelitian tindakan pada pertemuan awal diluar skenario, guru melakukan perkenalan dengan siswa, menyampaikan dan menjelaskan model pembelajaran yang akan digunakan beserta langkah-langkahnya.

\section{Tindakan Siklus I}

a. Perencanaan

Setelah ditetapkan untuk menerapkan model pembelajaran berbasis masalah (problem based learning), maka kegiatan selanjutnya adalah menyiapkan beberapa hal yang diperlukan pada saat pelaksanaan tindakan. Setelah berkonsultasi dengan guru mitra sebagai observer, peneliti melakukan hal-hal seperti: (1) Membuat skenario pembelajaran yang dituangkan dalam satu Rencana Pelaksanaan Pembelajaran (RPP) tindakan siklus I, (2) Membuat lembar observasi untuk mengamati aktivitas guru dan keaktifan belajar siswa pada saat pembelajaran dengan model pembelajaran berbasis masalah, (3) Menyiapkan bahan ajar dan media pembelajaran, (4) Membuat lembar kerja siswa (LKS), (5) Membuat soal sebagai alat evaluasi untuk tes tindakan siklus I.

b. Pelaksanaan tindakan

Pelaksanaan tindakan pembelajaran siklus I dilaksanakan pada hari Sabtu 16 Maret 2019 satu kali pertemuan 2 x 45 menit dengan Kompetensi Dasar (KD) yang diajarkan, yaitu menganalisis konflik sosial dan cara memberikan respons untuk melakukan resolusi konflik demi terciptanya kehidupan yang damai di masyarakat. Adapun materi pokok yang diajarkan yaitu, Akar masalah dan sebab-sebab terjadinya konflik. Pada akhir pertemuan siklus I dilaksanakan tes evaluasi siklus I. Penelitian dilaksanakan berdasarkan skenario pembelajaran yang telah dibuat. Pelaksanaan tindakan dilakukan oleh peneliti yang bertindak sebagai guru. Proses pelaksanaan tindakan pembelajaran disesuaikan dengan prosedur pelaksanaan model pembelajaran berbasis masalah (prolem based learning).

c. Observasi dan Evaluasi

Untuk mengetahui tingkat efektifitas mengajar guru dan tingkat keaktifan belajar siswa saat pembelajaran sosiologi berlangsung pada siklus I dengan model pembelajaran berbasis masalah (problem based learning) maka dilakukan pengamatan yang dinilai oleh guru mitra.

1) Observasi Efektifitas Mengajar Guru

Pengamatan efektifitas mengajar guru bertujuan untuk mengetahui kemampuan guru mengaktifkan siswa saat pembelajaran sosiologi dengan menerapkan model pembelajaran berbasis masalah (problem based learning). Efektifitas mengajar peneliti yang diobservasi berdasarkan model pembelajaran berbasis masalah meliputi: (1) Guru mengaitkan materi/tema/kegiatan pembelajaran yang akan dilakukan dengan pengalaman peserta didik dengan materi/tema/kegiatan sebelumnya (2) Guru memberikan gambaran tentang manfaat mempelajari pelajaran yang akan dipelajari dalam kehidupan sehari-hari (3) Guru memberitahukan materi pokok yang akan dibahas (4) Guru menyampaikan tujuan pembelajaran kepada siswa sebelum proses belajar mengajar (5) Guru menjelaskan mekanisme pelaksanaan pengalaman belajar sesuai dengan langkah-langkah pembelajaran (6) Guru memberikan penjelasan pengantar kegiatan secara garis besar/global tentang materi pembelajaran (7) Guru membagi peserta didik dalam 4 kelompok (8) Guru memberikan LKS pada siswa untuk diselidiki dengan masing-masing teman kelompok (9) Guru menayangkan video yang relevan dengan materi pokok (10) Guru mengarahkan siswa untuk mendiskusikan hasil pengamatan masing-masing kelompok kemudian mempresentasikannya (11) guru mengarahkan perwakilan kelompok untuk mempresentasikan hasil pengamatan masingmasing kelompok (12) Guru bersama siswa menyimpulkan materi yang telah diajarkan (13) Guru memberikan tes evaluasi. Berdasarkan observasi pembelajaran siklus I, diperoleh keberhasilan pembelajaran yang dilaksanakan guru sesuai dengan model pembelajaran berbasis.

Berdasarkan hasil observasi efektifitas mengajar guru dengan penerapan model pembelajaran berbasis masalah (problem based learning) siklus I skor yang diperoleh yaitu 11 sedangkan skor maksimum 13 hasil perhitungan persentase efektifitas mengajar guru diperoleh $84,61 \%$ dimana dari 13 indikator 2 aspek tidak terlaksana yaitu guru tidak menjelaskan mekanisme pelaksanaan pengalaman belajar sesuai dengan langkah-langkah pembelajaran dan tidak menyimpulkan materi pelajaran yang diajarkan bersama siswa. Hal tersebut menunjukkan bahwa 
efektifitas guru belum mencapai indikator kinerja yaitu 90\% telah dilaksanakan sesuai dengan skenario pembelajaran berbasis masalah (problem based learning) sehingga efektifitas mengajar guru belum nampak pada siklus I.

2) Observasi Aktivitas Belajar Siswa

Aktivitas belajar siswa yang diobservasi berdasarkan model pembelajaran berbasis masalah (problem based learning) meliputi : (1) Siswa mengaitkan materi pembelajaran yang akan dilakukan dengan materi pembelajaran yang telah dipelajari sebelumnya (2) Siswa menyimak manfaat mempelajari materi pokok yang akan dibahas dalam kehidupan sehari-hari (3) Siswa mencatat materi pokok yang akan dibahas (4) Siswa mencatat tujuan pembelajaran dari materi pokok yang akan dibahas (5) Siswa memperhatikan penjelasan langkah-langkah pembelajaran yang akan dilaksanakan (6) Siswa memperhatikan penjelasan pengantar secara global tentang materi pelajaran (7) Siswa bergabung dengan teman kelompok (8) Siswa menyimak tayangan video yang relevan dengan materi pokok (9) Siswa berdiskusi bersama teman kelompoknya (10) Siswa mempersentasikan hasil diskusi kelompoknya (11) Siswa bersama guru menyimpulkan materi yang telah dipelajari (12) Siswa mengerjakan tes evaluasi. Aktivitas belajar siswa berdasarkan observasi siklus I, diperoleh keberhasilan aktivitas belajar siswa sesuai dengan model pembelajaran berbasis masalah (problem based learning)

Berdasarkan hasil observasi aktivitas belajar siswa dengan penerapan model pembelajaran berbasis masalah (problem based learning) siklus I skor yang diperoleh yaitu 10 sedangkan skor maksimum 12. Hasil perhitungan persentase efektifitas mengajar guru diperoleh $75 \%$ dimana dari 12 indikator 2 aspek tidak terlaksana yaitu siswa tidak mengetahui langkah-langkah pembelajaran yang akan dilaksanakan dan tidak menyimpulkan materi yang telah dipelajari. Hal tersebut menunjukkan bahwa aktivitas belajar siswa belum mencapai indikator kinerja yaitu $90 \%$ telah dilaksanakan sesuai dengan skenario pembelajaran berbasis masalah (problem based learning) sehingga aktivitas belajar siswa belum nampak pada siklus I.

3) Evaluasi Hasil Belajar Siswa

Setelah pelaksanaan tindakan dalam pembelajaran sosiologi dengan model pembelajaran berbasis masalah (problem based learning) siklus I dilakukan tes evaluasi hasil belajar siswa dengan bentuk tes uraian. Dari hasil tes evaluasi hasil belajar siklus I kemudian dianalisis untuk menentukan ketuntasan belajar siswa. Hasil analisis ketuntasan belajar siswa pada siklus I dapat dilihat pada

Tabel 1. Hasil Analisis Ketuntasan Hasil Belajar Siklus I

\begin{tabular}{lccc}
\hline \multicolumn{1}{c}{ Skor } & Jumlah Siswa & Persentase (\%) & Ketuntasan Belajar \\
\hline $0-72$ & 7 & 26,92 & Tidak Tuntas \\
$73-100$ & 16 & 61,53 & Tuntas \\
Jumlah & $26(-3)$ & 100 & \\
Keterangan : & & & \\
Tuntas & $: 16$ Orang \\
Tidak Tuntas & $: 7$ Orang \\
Siswa Tidak Hadir & $: 3$ Orang \\
Nilai rata-rata & $: 79,56$ & \\
\% Ketuntasan & $: 61,53 \%$ & & \\
\hline
\end{tabular}

Sumber: Diolah Dari Hasil Penelitian

Tabel diatas menunjukkan bahwa pada pembelajaran siklus I, siswa yang memperoleh nilai antara 0-72 sejumlah 7 orang (26,92\%), siswa yang memperoleh nilai rentang 73-100 sejumlah 16 orang $(61,53 \%)$. Ketuntasan belajar siswa mencapai $61,53 \%$ dimana siswa yang memperoleh nilai $\geq 73$ sejumlah 16 orang, sedangkan 7 orang siswa belum tuntas dan 3 orang siswa yang tidak mengikut tes evaluasi. 
d. Refleksi

Pada tahap ini peneliti dan guru mitra bersama-sama menganalisis kekurangan-kekurangan pelaksanaan pembelajaran pada tindakan siklus I yang berkaitan dengan efektifitas mengajar guru, aktivitas belajar siswa dan hasil belajar siswa. Efektifitas mengajar guru pada tindakan pembelajaran siklus I belum optimal yang menjadi sebab utama yaitu karena guru belum melaksanakan sesuai dengan langkah-langkah pembelajaran problem based learning secara maksimal dimana guru belum mampu mengorganisasikan dengan baik langkah-langkah pembelajaran berbasis masalah pada siswa, tidak menyimpulkan materi pembelajaran yang dipelajari bersama siswa, serta persiapan alat pembelajaran yang kurang baik dimana guru memutar cuplikan video namun suara video yang diputar tidak dapat didengarkan dengan baik oleh siswa sehingga informasi yang ada pada video yang diputar tidak maksimal diketahui seharusnya guru melengkapi peralatan/media pembelajaran dengan pengeras suara agar maksimal. Sedangkan aktivitas siswa dalam pembelajaran berbasis masalah juga belum efektif masih terdapat siswa yang belum mampu mendefinisikan dan diorganisasikan tugasnya dengan baik serta kurang konsentrasi saat belajar.

Hasil belajar sosiologi siswa kelas XI MA Annur Azzubadi setelah diajar dengan model pembelajaran berbasis masalah berdasarkan hasil tes siklus I hanya mencapai $61,53 \%$ siswa yang tuntas dengan nilai rata-rata 79,56. Sesuai hasil analisis penelitian bersama guru mitra, penyebab rendahnya hasil belajar pada siklus I yaitu berpengaruh terhadap pelaksanaan proses pembelajaran, dimana masih terdapat aktivitas guru dan siswa yang tidak terlaksana dan belum optimal dilakukan sesuai dengan skenario pembelajaran, seperti yang dikemukakan diatas. Penelitian akan dilanjutkan pada siklus II karena indikator kinerja efektifitas mengajar guru, aktivitas belajar siswa dan hasil belajar siswa masih tergolong rendah. Pada siklus II diharapkan dilakukan perbaikan pada hal-hal yang belum maksimal pada pelaksanaan tindakan siklus I.

\section{Tindakan Siklus II}

a. Perencanaan

Setelah pelaksanaan tindakan siklus I terlaksana diketahui bahwa efektifitas mengajar guru, aktivitas belajar siswa dan ketuntasan belajar belum mencapai indikator maka pada siklus II dilakukan perbaikan kekurangan-kekurangan dalam pembelajaran siklus I, kegiatan selanjutnya adalah menyiapkan beberapa hal yang diperlukan pada saat pelaksanaan tindakan. Setelah berkonsultasi dengan guru mitra sebagai observer, peneliti melakukan hal-hal seperti : (1) Membuat skenario pembelajaran yang dituangkan dalam satu Rencana Pelaksanaan Pembelajaran (RPP) tindakan siklus II (2) Membuat lembar observasi untuk mengamati aktivitas guru dan keaktifan belajar siswa pada saat pembelajaran dengan model pembelajaran berbasis masalah, (3) Menyiapkan bahan ajar dan media pembelajaran, (4) Membuat lembar kegiatan siswa (LKS), (5) Membuat soal sebagai alat evaluasi untuk tes tindakan siklus II.

b. Pelaksanaan tindakan

Pelaksanaan tindakan pembelajaran siklus II dilaksanakan pada hari Sabtu 23 Maret 2019 satu kali pertemuan 2 x 45 menit dengan Kompetensi Dasar (KD) yang diajarkan yaitu, menganalisis konflik sosial dan cara memberikan respon untuk melakukan resolusi konflik demi terciptanya kehidupan yang damai di masyarakat. Adapun materi pokok yang diajarkan yaitu Resolusi Konflik (Pencegahan, Pengelolaan, Rekonsiliasi, dan Transformasi). Pada akhir pertemuan siklus II dilaksanakan tes evaluasi siklus II. Penelitian dilaksanakan berdasarkan skenario pembelajaran yang telah dibuat. Pelaksanaan tindakan siklus II dilakukan oleh peneliti yang bertindak sebagai guru. Proses pelaksanaan tindakan pembelajaran disesuaikan dengan prosedur pelaksanaan model pembelajaran berbasis masalah (prolem based learning).

c. Observasi dan Evaluasi

Untuk mengetahui tingkat efektifitas mengajar guru dan tingkat keaktifan belajar siswa saat pembelajaran sosiologi berlangsung pada siklus II dengan model pembelajaran berbasis masalah (problem based learning) maka dilakukan pengamatan yang di nilai oleh guru mitra.

1) Observasi efektifitas mengajar guru 
Pengamatan efektifitas mengajar guru bertujuan untuk mengetahui kemampuan guru mengaktifkan siswa saat pembelajaran sosiologi dengan menerapkan model pembelajaran berbasis masalah (problem based learning). Efektifitas mengajar peneliti yang diobservasi berdasarkan model pembelajaran berbasis masalah meliputi: (1) Guru mengaitkan materi/tema/kegiatan pembelajaran yang akan dilakukan dengan pengalaman peserta didik dengan materi/tema/kegiatan sebelumnya (2) Guru memberikan gambaran tentang manfaat mempelajari pelajaran yang akan dipelajari dalam kehidupan sehari-hari (3) Guru memberitahukan materi pokok yang akan dibahas (4) Guru menyampaikan tujuan pembelajaran kepada siswa sebelum proses belajar mengajar (5) Guru menjelaskan mekanisme pelaksanaan pengalaman belajar sesuai dengan langkah-langkah pembelajaran (6) Guru memberikan penjelasan pengantar kegiatan secara garis besar/global tentang materi pembelajaran (7) Guru membagi peserta didik dalam 4 kelompok (8) Guru memberikan LKS pada siswa untuk diselidiki dengan masing-masing teman kelompok (9) Guru mengarahkan siswa untuk mendiskusikan hasil pengamatan masing-masing kelompok kemudian mempresentasikannya (10) Guru mengarahkan perwakilan kelompok untuk mempresentasikan hasil pengamatan masing- masing kelompok (11) Guru bersama siswa menyimpulkan materi yang telah diajarkan (12) Guru memberikan tes evaluasi.

Dari hasil observasi efektifitas mengajar guru dengan penerapan model pembelajaran berbasis masalah (problem based learning) siklus II skor yang diperoleh yaitu 12 memperoleh skor maksimum. Hasil perhitungan persentase efektifitas mengajar guru diperoleh $100 \%$ hal tersebut menunjukkan bahwa efektifitas guru telah mencapai indikator kinerja yaitu $90 \%$ telah dilaksanakan sesuai dengan skenario pembelajaran berbasis masalah (problem based learning) sehingga efektifitas mengajar guru telah mencapai indikator kinerja pada Siklus II.

2) Observasi Aktivitas Belajar Siswa

Aktivitas belajar siswa yang diobservasi berdasarkan model pembelajaran berbasis masalah (problem based learning) meliputi : (1) Siswa mengaitkan materi pembelajaran yang akan dilakukan dengan materi pembelajaran yang telah dipelajari sebelumnya (2) Siswa menyimak manfaat mempelajari materi pokok yang akan dibahas dalam kehidupan sehari-hari (3) Siswa mencatat materi pokok yang akan dibahas (4) Siswa mencatat tujuan pembelajaran dari materi pokok yang akan dibahas (5) Siswa memperhatikan penjelasan langkah-langkah pembelajaran yang akan dilaksanakan (6) Siswa memperhatikan penjelasan pengantar secara global tentang materi pelajaran (7) Siswa bergabung dengan teman kelompok (8) Siswa menyelidiki LKS dengan masing-masing teman kelompok (9) Siswa berdiskusi bersama teman kelompoknya (10) Siswa mempresentasikan hasil diskusi kelompoknya (11) Siswa bersama guru menyimpulkan materi yang telah dipelajari (12) Siswa mengerjakan tes evaluasi. Berdasarkan hasil observasi aktivitas belajar siswa dengan penerapan model pembelajaran berbasis masalah (problem based learning) siklus II skor yang diperoleh yaitu 12 memenuhi skor maksimum. Hasil perhitungan persentase aktivitas belajar siswa diperoleh $100 \%$ hal tersebut menunjukkan bahwa aktivitas belajar siswa sudah mencapai indikator kinerja yaitu 90\% telah dilaksanakan sesuai dengan skenario pembelajaran berbasis masalah problem based learning sehingga aktivitas belajar siswa pada siklus II telah mencapai indikator kerja.

3) Evaluasi Hasil Belajar Siswa

Setelah pelaksanan tindakan dalam pembelajaran sosiologi dengan model pembelajaran berbasis masalah (problem based learning) siklus II dilakukan tes evaluasi dengan bentuk tes uraian. Hasil Evaluasi Tes Uraian siklus II. Dari hasil tes siklus II kemudian dianalisis untuk menentukan ketuntasan belajar siswa. Hasil analisis ketuntasan belajar siswa pada siklus II 
Tabel 2. Analisis Ketuntasan Hasil Belajar Siklus II

\begin{tabular}{|c|c|c|c|}
\hline Skor & Jumlah Siswa & Persentase \% & Ketuntasan Belajar \\
\hline $0-72$ & 4 & 18,18 & Tidak Tuntas \\
\hline 73-100 & 19 & 82,60 & Tuntas \\
\hline Jumlah & $26(-3)$ & 100 & \\
\hline \multicolumn{4}{|l|}{ Keterangan : } \\
\hline Tuntas & \multicolumn{2}{|l|}{ : 19 Orang } & \\
\hline Tidak Tuntas & \multicolumn{2}{|l|}{ : 4 Orang } & \\
\hline Siswa Tidak Hadir & \multicolumn{2}{|l|}{ : 3 Orang } & \\
\hline Nilai rata-rata & \multicolumn{2}{|l|}{ : 88,12 } & \\
\hline$\%$ Ketuntasan & \multicolumn{2}{|l|}{ : $82,60 \%$} & \\
\hline
\end{tabular}

Sumber: Diolah Dari Hasil penelitian

Tabel diatas menunjukkan bahwa pada pembelajaran siklus II, siswa yang memperoleh nilai antara 0-72 sejumlah 4 orang (18,18\%), siswa yang memperoleh nilai rentang 73-100 sejumlah 19 orang $(82,60 \%)$. Ketuntasan belajar siswa mencapai $82,60 \%$ dimana siswa yang memperoleh nilai $\geq 73$ sejumlah 19 orang, sedangkan 4 orang siswa belum tuntas dan 3 orang siswa tidak mengikuti tes evaluasi. Hal tersebut menunjukkan bahwa ketuntasan hasil belajar pada tindakan siklus II telah mencapai indikator kinerja yaitu $80 \%$ ketuntasan hasil belajar siswa.

d. Refleksi

Berdasarkan hasil observasi efektivitas mengajar guru, aktivitas belajar siswa dan ketuntasan belajar siswa pada tindakan siklus II dengan menerapkan model pembelajaran berbasis masalah (problem based learning) secara signfikan dapat terlihat meningkat dan mencapai indikator kerja untuk setiap aspek-aspek yang diamati. Efektifitas mengajar guru telah meningkat setelah mengoptimalkan langkah-langkah pembelajaran berbasis masalah (problem based learning) juga kemampuan guru mengelola kelas serta siswa yang turut aktif dalam kegiatan penyelidikan masing-masing kelompok sehingga ketuntasan belajar mengalami peningkatan. Dengan demikian penelitian tindakan berakhir pada siklus II.

\section{B. Pembahasan}

Penelitian ini dilakukan untuk meningkatkan hasil belajar mata pelajaran sosiologi di MA Annur Azzubaidi kelas XI IPS dengan menerapkan model pembelajaran berbasis masalah (problem based learning). Penelitian ini dilakukan melalui beberapa tahap yaitu observasi awal dan penelitian tindakan yang terdiri dari II siklus. Observasi awal dilakukan untuk mendapatkan informasi ketuntasan hasil belajar siswa yang belum menggunakan model pembelajaran berbasis masalah (problem based learning) dari hasil observasi awal yang diamati oleh peneliti dan dilakukan tes evaluasi berupa tes uraian didapatkan informasi bahwa hasil belajar siswa yang masih tergolong rendah, sebagian besar belum mencapai KKM yang ditetapkan disekolah yaitu 72 . Data yang diperoleh bahwa ketuntasan belajar siswa berdasarkan hasil tes observasi awal yaitu $30,76 \%$ berdasarkan hal itu perlu dilakukan penerapan model pembelajaran yang dapat meningkatkan hasil belajar siswa salah satunya dengan model pembelajaran berbasis masalah (problem based learning) serta melihat kecocokan model pembelajaran yang disesuaikan materi pokok yang akan diajarkan. Saat pembelajaran berlangsung aspek yang menjadi pengamatan penelitian tindakan peneliti yaitu efektifitas mengajar guru, aktivitas belajar siswa dan hasil belajar siswa.

Untuk mengetahui perkembangan keterlaksanaan efektifitas mengajar guru, aktivitas belajar siswa, dan peningkatan hasil belajar siswa melalui penerapan model pembelajaran berbasis masalah pada siklus I dan siklus II dapat dilihat pada tabel 3 dibawah ini. 
Tabel 3. Perkembangan Keterlaksanaan Efektifitas Mengajar Guru, Aktivitas Belajar Siswa, dan Peningkatan Hasil Belajar Siswa Setiap Siklus.

\begin{tabular}{ccccccc}
\hline Tindakan & \multicolumn{2}{c}{$\begin{array}{c}\text { Persentase } \\
\text { Aktivitas }\end{array}$} & \multicolumn{3}{c}{ Hasil Belajar } \\
\cline { 2 - 7 } & Guru & Siswa & Jumlah & Rata-rata & \multicolumn{2}{c}{ Persentase } \\
& & & & & Tuntas & Tidak Tuntas \\
Siklus I & $84,61 \%$ & $83,33 \%$ & 1830 & 79,56 & $61,53 \%$ & $26,92 \%$ \\
Siklus II & $100 \%$ & $100 \%$ & 2115 & 88,12 & $82,60 \%$ & $18,18 \%$ \\
\hline
\end{tabular}

Sumber: Diolah Dari Hasil Penelitian.

Berdasarkan table tersebut maka dapat diuraikan sebagai berikut:

1. Efektifitas Mengajar Guru; efektifitas mengajar guru dengan penerapan model pembelajaran berbasis masalah (problem based learning) meningkat secara signifikan dimana pada siklus I diperoleh persentase efektifitas mengajar guru $84,61 \%$ kemudian meningkat pada siklus II $100 \%$ setelah dilakukan perbaikan pada kekurangan-kekurangan pelaksanaan tindakan pada siklus I.

2. Aktivitas Belajar Siswa; aktivitas belajar siswa meningkat dengan persentase yang signifikan dimana pada siklus I 83,33\% meningkat pada siklus II 100\% dengan mengoptimalkan pengelolaan kelas dan langkah-langkah model pembelajaran berbasis masalah (problem based learning) yang kurang baik pada siklus I.

3. Hasil Belajar Siswa; hasil belajar siswa meningkat dengan penerapan model pembelajaran berbasis masalah dengan nilai rata-rata pada siklus I 79,56 dimana 16 orang siswa tuntas , 7 orang siswa tidak tuntas. Ketuntasan hasil belajar dengan persentase pada siklus I 61,53\% meningkat pada siklus II 82,60\%. Pada siklus II nilai rata-rata siswa 88,12 dimana 19 orang siswa tuntas mencapai nilai KKM, 4 orang siswa tidak mencapai nilai KKM. Indikator persentase ketuntasan belajar siswa yang ditetapkan yaitu $80 \%$. Berdasarkan data hasil penelitian pada siklus II maka hipotesis tindakan telah tercapai bahwa penerapan model pembelajaran berbasis masalah (problem based learning) dapat meningkatkan hasil belajar sosiologi kelas XI IPS MA Annur Azzubaidi.

\section{PENUTUP}

Berdasarkan hasil penelitian tindakan kelas dengan menerapkan model pembelajaran berbasis masalah (problem based learning) dalam pembelajaran sosiologi kelas XI IPS MA Annur Azzubaidi disimpulkan sebagai berikut: Pertama penerapan model pembelajaran berbasis masalah (problem based learning) dapat meningkatkan efektivitas mengajar guru sosiologi kelas XI IPS MA Annur Azzubaidi. Hal ini ditunjukkan dengan peningkatan persentase efektivitas mengajar guru dari siklus I sebesar $84,61 \%$ meningkat menjadi $100 \%$ pada siklus II. Kedua penerapan model pembelajaran berbasis masalah dapat meningkatkan aktivitas belajar siswa kelas XI IPS MA Annur Azzubaidi. Hal ini dilihat dari persentase aktivitas belajar siswa siklus I sebesar 83,33\% meningkat menjadi $100 \%$ pada siklus II. Ketiga penerapan model pembelajaran berbasis masalah (problem based learning) dapat meningkatkan hasil belajar sosiologi kelas XI IPS MA Annur Azzubaidi. Hal ini ditunjukkan dengan peningkatan persentase hasil belajar siswa dari siklus I dengan nilai rata-rata 79,56 dan persentase ketuntasan sebesar $61,53 \%$ kemudian meningkat dengan nilai rata-rata 88,12 serta persentase ketuntasan sebesar $82,60 \%$ pada siklus II.

\section{DAFTAR PUSTAKA}

Abbas, Nurhayati. 2000. Pengembangan Perangkat Pembelajaran Matematika Berdasarkan Masalah (Problem-Based Instruction).Tesis. Surabaya: Program Studi Pendidikan Matematika Program Pasca Sarjana Unesa. 
Ahmadi, Rulam. 2016. Pengantar Pendidikan: Asas \& Filsafat Pendidikan. Yogyakarta: Ar-Ruzz Media

Aqib, Zaenal. 2007. Penelitian Tindakan Kelas Bagi Pengembangan Profesi Guru. Bandung: Yrama Widya.

Djamarah, Syaiful Bahri dan Aswan Zain. 2002. Strategi Belajar Mengajar. Jakarta: Rineka Cipta.

Putra, Yanuar Saputra. 2016 "Theoritical Review: Teori Perbedaan Generasi”. Among Makarti Vol 9 No.18, Hal.123-134.

Sugiyono. 2006. Statistik untuk penelitian. Bandung: Alfabeta.

Suwardana, Hendra. 2017 "Revolusi Industri 4.0 Berbasis Revolusi Mental" Teknik Industri, Universitas PGRI Ronggolawe Tuban. Vol.1, No. 2 Hal.102-110.

Syukri, Muhammad. 2011. Penelitian Tindakan Kelas. Modul. Jakarta: Dirjen Dikti Departemen Pendidikan Nasional.

Udin, Winatapura dkk. 1994. Strategi Belajar Mengajar IPA. Jakarta: Universitas Terbuka. 